\title{
Implementation Of New Public Service In Policing: The Role Of Citizen Police Academies
}

\author{
Murat Ozkan \\ Turkish National Police, Turkey
}

doi: 10.19044/esj.2016.v12n11p156 URL:http://dx.doi.org/10.19044/esj.2016.v12n11p156

\begin{abstract}
The New Public Service encourages involving citizens in decisionmaking process of governing. Community policing approach relies on active community relations and input. Citizen Police Academies (CPA's) served both purposes. This study discusses the tenets of the New Public Service and evaluates CPA's impact on citizen satisfaction and attitude toward police. It presents CPA's and similar programs as an effective tool to increase police citizen interaction and to gain community support.
\end{abstract}

Keywords: Citizen police academies, community policing, New Public Service, police and community

\section{Introduction}

Democracy is one of the core values of modern society (Kathi and Cooper, 2005), and it is the most enunciated word on today's world. Experiencing different kinds of management strategies, human beings have understood that democracy is the best way to govern the countries. Democracy can be simply defined as the rule of people, so it requires the participation of people to both policy making and administration facilities. In this point of view "The New Public Service" accept citizens as citizens, not customers. Individuals are not merely customers, but they are citizens. Democratic citizenship requires active and involved citizens. Not only are the individuals mere citizens, but also they must engage, and participate decision making process of governing. Citizens are the owner of the government; therefore they should be in the decision-making process. People must be empowered by being brought to decision making process. The only way to do this is educating people about policies and process.

Community policing is an implementation of "The New Public Service" in the policing field. Policing is one of the common services in people's daily life, and may be one of the most visible services (Darcan, 2014). Unlike the traditional policing where the police act as law- 
enforcement agents, the basic assumption of community policing is that police departments cannot truly implement crime prevention strategies without cooperating with the community.

Modern policing demands more interactions between the police and the community so that crime can be diminished and the quality of life can be promoted. The goal of community policing is to meet the community in noncriminal situations and get in touch with law-abiding people. Community policing has been used in the U.S. and in other countries and has become a major paradigm in contemporary policing. The main goal of community policing is to promote the relationship between the police and the community. One of the most important dynamic forces behind the movement toward community policing was the wish to promote the relationship between the citizens and the police since the 1970's (Ling, Liqun, Lovrich \& Gaffney, 2005).

Satisfying police service consumers - "the citizens" - is an important aspect for police to enhance the relationship between the police and the policed. Therefore, law enforcement agencies have implemented various programs to improve their cooperation with the public and increase citizens' satisfaction with police. Community policing assumes that residents are willing to cooperate with the police (Hawdon \& Ryan, 2003, p.58). This assumption indeed paved the way for many community programs that required active participation of citizens. Citizen Police Academies (CPA's) are among these that aimed to build stronger bonds between the police and the public. The implementation process of a policy plays crucial role to understand the compliance between the goals of the program and the outcomes (Kapti and Alaç, 2013). In this point of view, CPA's can be seen as a good implementation of New Public Service tenets which reaffirms the democratic values such as citizen participation to policing in the security sector.

The New Public Service approach is developed by Denhardt and Denhardt. They rely on three theories as the roots of the New Public Service; theories of democratic citizenship, models of community and civil society, and organizational humanism and discourse theory. This article will mainly focus on the tenets of the New Public Service in the first part citing mainly the Denhardts' assumptions. It will then apply these assumptions or tenets of the New Public Service to one of the policing approach; the community policing, in fact the Citizen Police Academies. The core assumptions of these concepts perfectly match. One can easily see the Citizen Police Academies initiative as a good implementation of the New Public Service Philosophy to the security sector. 


\section{The New Public Service: Reaffirming the Democratic Values}

Democracy is known as the best system which human beings reach today. Democracy can be simply defined as the rule of people, so it requires the participation of people for both policy making and administration.

Democracy is one of the core values of American society, and it requires the citizen participation in government decision making. This participation promotes efficiency and effectiveness of government (Kathi and Cooper, 2005).

In "The New Public Service: Serving, not Steering”, Denhardt \& Denhardt (2003) synthesize some of the ideas for the reaffirmation of democratic values for public administration field, and then provide a framework for "The New Public Service" based on democratic values, citizenship, and service to people. Denhardt \& Denhardt (2000) classifies the roots of the New Public Service in three theories: theories of democratic citizenship, models of community and civil society, and organizational humanism and discourse theory. Theories of democratic citizenship see individuals as citizens and citizens are much more actively engaged in governance. In the models of community and civil society, people work out their personal interests in small groups called "civil society". Citizens engage in these small groups and governmental units. Finally, organizational humanism and discourse theory maintain that an open discourse among citizens and administrators is the basis of governance. Denhardt and Denhardt (2003) add a fourth root for New Public Service in their book. This theoretical root is postmodernism. Discourse is the main central commitment for postmodern public administrators. Although some public administration theorists believe that public problems are more likely resolved through objective measurements, postmodern public administrators believe that public problems are more likely resolved through discourse.

The new public service reaffirms the values of democracy, and democratic citizenship. Denhardt and Denhardt (2003) basically point that "Government shouldn't be run like a business; it should be run like a democracy." This is the basic principle of the new public service. They have seven basic tenets for their framework:

Serve Citizens, Not Customers. The new public service reaffirms the citizenship values. Unlikely, in the traditional public administration, people were seen as clients which means "dependent" in Latin. Clients were dependent to the government, and government help clients. The new public management has accepted people as customers, and addressed that government should be run like a business. Osborne and Gaebler (1992) pointed out that customer satisfaction should be the main concern of the government, and entrepreneurial public services should be given to the customers. Mintzberg (1996) rejects being a mere customer of his 
government, and mentions different relationships of citizens with their governments. He describes the "customer" concept as confining and adds "I am a citizen, with rights that go far beyond those of customers or even clients (p. 77)." Similarly the New Public Service has argued that all citizens are not the customer of the government. The government and its agencies should provide quality service for citizens.

Seek the Public Interest. Centrality of the public interest in government service is one of the core principles of the new public service. In the traditional public service, elected policymakers defined the public interest, and administrators were assumed to best serve the public interest by implementing laws in neutral manner. The domination of the new public management overshadowed the shared view of the public interest. In contrast, public managers have a central and crucial role in helping citizens to articulate the public interest. Listening, being democratic, being dispersing are important for the public managers, and they are the facilitators (Denhardt \& Denhardt, 2000; Denhardt \& Denhardt, 2003).

Value Citizenship over Entrepreneurship. Entrepreneurial managers may overlook the public interest. However, Public servants can better understand the public interest with citizens. Administrators have more active role in the policy process in the new public management, the role of policy entrepreneur. Besides this roles, managers were urged to respond to customer demands in the new public management. Unlike the new public management, the new public service stimulates the involvement of citizens to the development of public policy (Denhardt \& Denhardt, 2000; Denhardt \& Denhardt, 2003). As Putnam (1995) states, engaged citizens, active in all sort of groups, associations, and governmental units are the basics of America's democratic tradition.

Think Strategically, Act Democratically. Collective efforts and collaborative processes can make it easy and effective to reach the policies and programs meeting public needs. Since the implementation was based on what the administration was responsible in the traditional public administration, collectiveness and collaboration can not be achieved because the process of policy implementation was top-down, hierarchical, and unidirectional. In contrast, government should "get out of the way" as much as possible to yield market forces in the new public management, so it doesn't deal with implementation directly. Separate from traditional and new public management, citizen engagement and community building are primary focus of implementation in the new public service (Denhardt \& Denhardt, 2003). Government and political leaders can not create community, but political leadership support individual citizens and groups which can create community (Denhardt \& Denhardt, 2000). 
Recognize that Accountability isn't Simple. A formal, hierarchical and legal view of accountability characterizes the traditional public administration. Administrators simply implement the laws, rules and standards set for them by their superiors, elected officials and the courts. Accountability should also be like in business model for the new public management which is performance measurement system. Public administrators must be accountable to everyone in the new public service involving balancing competing norms and responsibilities within a complicated web of external controls, citizen preferences, moral issues, public law, and the public interest (Denhardt \& Denhardt, 2003). Public administrators do not make the decisions alone in the New Public Service. The decision process goes through dialogue, citizen empowerment, and broad-based citizen engagement. Since public administrators are supposed to make decisions with citizens, they can make realistic and effective solutions to problems. Thus, this interaction builds both citizenship and accountability (Denhardt \& Denhardt, 2000).

Denhardt and Denhardt's (2003) sixth tenets of New Public Service is Serve rather than Steer. New public management addresses entrepreneurship as a way to lead the society. In the new public service, public administrators have responsibility to serve citizens, and they are the facilitators of democratic dialogue. Leadership is based on values and shared throughout the organization and with the community.

Value People, Not just Productivity is the last tenets of Denhardt and Denhardt (2003). The new public management assumes that people are self interested and monitoring them and providing enough incentives can ensure their productivity. Participative and inclusive approaches are the ways that builds citizenship, responsibility and trust in the new public service. Workers should be permitted to participate, and managers should encourage their employees to be authentic.

\section{Community policing as an implementation of "The New Public Service"}

Citizens are not customers in the new public service. Rather, public administrators are considered to be the servant, and they have different roles; such as, conciliating, mediating, and catalyzing for community engagement other than just performing service delivery. Accountability is not simple but very important. Public administrator should also value people, not just productivity. In addition to these, participation is necessary to empower citizens. Public administrators must bring people to the decision making process. Therefore they must educate people about policies and processes (Denhardt and Denhardt, 2001, 2003).

The principals of the new public service can be implemented in the policing field, because policing is one of the common fields in which citizens 
and public administrators interact. Both citizens and police need each other mutually to better serve and be better served. In traditional policing, police act just as law-enforcement agents, and the focus was to reduce crime rates by strictly enforcing the laws. Investigation and arrest were the basic police jobs (Xu, Fiedler and Flaming, 2005). In the traditional policing the aim was reducing the crime rates, and the success was measured according to the productivity which was the number of arrest made, crime clearance rates and so on. MacDonald (2002) adds high visibility, and low response time as two other aims of traditional policing. These performances might seem a success or serve as temporarily solutions of public order and people's life of quality. However, from the success of police efforts emerged a new problem; full prisons, and jails. Besides this, unsolved and organizational crimes stayed as a threat to society. It was witnessed that without community support, police can have limited success in their work.

Community policing takes a comprehensive approach to these problems, and embraces the cooperation and partnerships and even active involvement of citizens to policing in order to improve the quality of life and reduce the fear of crime (Roh, \& Oliver, 2005; Xu et al., 2005). Although there is no agreed upon definition, community policing has been defined in many similar ways. For instance, it is defined as a practice for greater sharing of data and prizes by the police and the residents, and a way for switching the police and their service to the residents (Greene, 1997). Trojanowicz and Bucqueroux defined community policing as; “... a new philosophy of policing, based on the concept that police officers and private citizens working together in creative ways can help solve contemporary community problems related to crime, fear of crime, social and physical disorder, and neighborhood decay" $(1990,5)$. Stevens notes that community policing focuses on "helping others to help themselves" (2002, 64). These definitions force the police to change from reactive to proactive policing; in other words, from crime fighter to problem-solvers.

Crime control, order maintenance and service provision are three functions of policing. Community policing prioritizes order maintenance and service provision. Neighborhood Watch Program, voluntary service within police departments, citizen patrol, citizen police academies, nomination of community officers, community-based foot patrols, regular meeting with community leaders, and in service training are typical community policing programs. These activities are directed toward the priorities of community policing, order maintenance and service provision (Zhao, He, and Lovrich, 2003). The philosophy of community policing comprises an organizational switch, growth of citizen accountability, decentralized decision-making, and authorization of line officers (Lumb \& Breazeale, 2003). In addition, 
community partnerships and joint problem-solving efforts are main components of community policing.

Crime statistics, number of arrests, and response times are some of performance measurement tools for police when policing is directed solely to crime fighting. In the community policing model, it is very hard to measure the effectiveness of police with classic models, because the aim in the community policing is to prevent the crimes before they happen, increase citizen's quality of life, and reduce fear of crime. MacDonald (2002) also points out that the evaluation of police- community partnership is very hard because of the broad scope of the concept. However, there have also been some longitudinal studies, cross-sectional studies, and multiple site evaluations on the effectiveness of community policing programs (Zhao, Scheider, and Thurman, 2002a).

$\mathrm{Xu}$ et al. (2005) found a significant effect of community policing variables (working with community and crime prevention) on disorder. Zhao, Scheider, and Thurman, (2002b) analyzed 50 studies on community policing and its effects on reducing fear of crime. They found that a reduction in fear was shown in 31, of the studies no change in fear was in 18, and a study reporting an increase was only one. A study conducted by Roh and Oliver in 2005 on community policing and fear of crime is consistent with the findings of Zhao et al (2002b) and shows that the community policing decreases fear of crime. MacDonald (2002) in one of the most visible patrol beat study in the Kansas City gun experiment found that a significant reduction in gun crimes was shown in the experimental beat which used community policing. MacDonald also found that proactive policing methods were effective for preventing violent crime. Zhao et al's (2003) findings on the implementation of community policing on all core functions of policing were statistically significant and therefore suggest that community policing programs are an effective means when used to control crime, decrease social disorder, and supply services to the community.

Providing comprehensive knowledge of police activities, practices, and culture facilitates the citizens' understanding of police. This can also ensure a robust cooperation between police and the community. In this point of view, police departments developed the Citizen Police Academies (CPA) to increase the understanding between citizens and police (Cohn, 1996; Palmiotto \& Unninthan, 2002).

\section{Citizen Police Academies (CPA)}

Satisfying police service consumers - "the citizens" - is an important aspect for police to enhance the relationship between the police and the policed. Therefore, law enforcement agencies have implemented various programs to improve their cooperation with the public and increase citizens' 
satisfaction with police. Community policing assumes that residents are willing to cooperate with the police (Hawdon \& Ryan, 2003, p.58). This assumption indeed paved the way for many community programs that required active participation of citizens. Citizen Police Academies (CPA's) are among these that aimed to build stronger bonds between the police and the public.

CPA's have gained quick attention and become widespread in the nation in order to provide a mechanism for community education (Greenberg, 1991, p.11). In these academies citizens are taught about police operations, policies and procedures. After its first application in Orlando, Florida, the academies were "increasingly recognized as one of the most important tactics of the public education component of community policing" (Peverly \& Phillips, 1993, p.88).

Since they are administered so frequently, many researchers have evaluated CPA's. (Cohn,1996; Bonello \& Schaefer, 2001; Aryani, 2000; Bumphus, Gaines, \& Blakely, 1999). These studies focused on different aspects ranging from the effects of CPA on the participants to the costbenefit analysis. Since the main argument of community policing (with all the ambiguity and controversy related to its definition) is to enhance the police community relations, it is vital that police community relations programs such as CPA's play a key role in increasing the citizen satisfaction.

Having mentioned the general context of CPA's, it should be noted that there is a significant difference between CPA's and police contact that is presented above in the frame of satisfaction with police. Unlike police contact which is spontaneous and most of the time occurs without prior planning, CPA's are preplanned and implemented purposefully to enhance community relations. Therefore, dynamics behind satisfaction resulting from police contact and CPA implementation differs in various aspects. The following section will provide background information about CPA structures and goals as well as their impact on attitudes toward police.

\section{History of CPA's}

Citizen Police Academies evolved in the United Kingdom in the 1977 (Aryani et al, 2000; Bonello \& Schafer, 2001) when police organizations and the local law enforcement established 'Police Night School' to meet with the citizens once a week for ten weeks (Aryani et al, 2000). It became so popular that various police departments applied similar programs in Britain. The first Citizen Police Academy was organized after Richard Overman of Orlando, Florida police department attended a British class and started a similar program in 1985. The idea of CPA quickly became popular and many police departments organized such programs (Stone \& Champeny, 2001,p.226). 


\section{The Structure of CPAs}

Almost all police departments administer these academies different in terms of curriculum and time period. However, despite all the ambiguity of the term "community policing”, there is common theme for CPA's, which is "Citizen Police Academies are usually shortened versions of law enforcement academies” (Enns, 1995). The first program in Orlando included following topics in 12 weeks (Whitman, 1993, p. 69); Introduction/Selection and Training; Laws of Arrest, Search and Seizure, Internal Affairs; Communications, Statistics, Planning, and Evaluation; Patrol Operations; Special Operations; Violent Crime Section; Property Section and Special Investigations; Special Investigations, Technical Services; Undercover Narcotic Operations, Vice Crimes; Special Teams; Youth Section, Community Involvement; Special Problems in Law Enforcement-Use of Force.

While some departments have mere two days program, some have ten weeks-length programs, and some have 13 weeks programs. Classes generally meet for two or more hours for each week. Naturally, classes meet after working hours or weekends. Some programs require participants to perform a certain activity, but it is usually ride along or having self-defense classes. However, this is not a mandatory for every department. The CPA curriculum varies from department to department. The most common topics that CPA's include are:, police selection and training, patrol procedures, domestic violence, police use of force, departmental organization, traffic stops, police stress and crime prevention. (Cohn, 1996, p.266; What's the Citizen Police Academy, 2004; Bumphus et al, 1999, p.75)

\section{Objectives of CPA's}

Unlike the structure and curriculum, the objectives of CPA's show little variance. "The general consensus, regarding the primary purpose, is to enhance public image of police”(Bumphus et al., 1999, p.69). The purposes of CPA implementation in Lansing, Michigan police department are identical to many programs;

"* To create a network of citizens who have a basic understanding about the workings of the department and the complexity of police work;

* To give CPA students the information they need for better evaluation of media reports about police performance; and

*To increase the likelihood that CPA graduates will work with officers to identify and solve neighborhood problems" (Bonello \& Schafer, 2001,p.438). 
Hilson (1994, p.1) claims that the ultimate goal of CPA is "the reduction of crime through a stronger citizen commitment to the police department and the community."

\section{The Effects of CPA's on Participants' Satisfaction with Police}

It is common to conduct surveys after each session of CPA's to see how the program works. Some departments do their own surveys by making interviews with citizens after graduation. East Syracuse Police Department, New York, surveyed the participants to observe the changes that have been occurred in participant's attitudes after graduation. The survey results reported that:

"Four common themes emerged:

1- An increased understanding of and appreciation for intelligence, versatility and professionalism of the "average" police officer;

2- An increased appreciation and support for continued training and formal education for police officers;

3- A decided willingness to be less influenced by the prejudices of others in conversations related to the police and;

4- An increased sense of individual responsibility to work with the police in matters related to order maintenance and crime prevention" (Peverly \& Phillips, 1993, p.89).

According to Cohn, "CPA participants learn about police department's operations, become more supportive of police work, and develop an increased awareness and appreciation of the job of the police, not only understanding what the police do but why they do what they do" (Cohn, 1996,266). Cohn (1996) continues that the police departments also learn about the citizens' expectations which help police develop a better understanding of citizens' concerns and their perceptions of the police.

It should be noted that some participants already had positive attitudes before the academy, but after the graduation almost everyone showed pro-police attitudes (Hilson, 1994, p.5). Citizens who graduated from Fannington, Connecticut CPA believed "the department had built invaluable bridges between itself and the community" (Enns, 1995, p.135).

Greenberg (1991, p.12) has noted some disadvantages of CPA programs. First, he exercises caution while implementing the program by revealing concerns that CPA's can possibly be turned into a public relations forum. On the other hand, he warns, "some instructors may go too far to the other extreme and spend all their time telling "war stories," rather than providing CPA participants with concrete information that they can take away and use" (Cohn, 1996, p.270). One of the main problems regarding CPA is that, by nature, the classes are too small, and overall effects of CPA's 
on a given neighborhood is therefore so limited (Cohn, 1996; Greenberg, 1991; Bumphus et al, 1999).

Overall, despite some disadvantages, many research findings suggest that the participants of CPA's report high level of satisfaction with police (Palmiotto \& Unninthan, 2002, p.101).

\section{Conclusion}

The roots of New Public Service come from democratic citizenship theories, model of community and civil society, organizational humanism, and postmodern public administration. The central point in New Public Service is the democratic values such as citizen involvement. One of the core values of modern society is democracy, and New Public Service also requires democratic values in public administration field. Citizen participation in decision making procedure of public administration field is essential for New Public Service. Borrowing Hood's (2002) theory, I have examined the situations where New Public Service strategies can be easily implemented. Community policing tools are used to measure the New Public Service. Community policing is a philosophy. It also reaffirms the democratic values into the policing field. Citizen involvement in policing activities is the basis of community policing. Interacting and cooperating with citizens, police can be very successful to prevent crime and also to increase the quality of life of citizens.

Since countries and states cannot provide a police for every citizen, every citizen should have a police in his or her heart. The effectiveness and success of security services requires community participation and cooperation. Community policing assumes some programs to ensure police and community interaction. Actually, community policing can reduce high incarceration rates through proactive policing activities. It is better both for community and police to prevent crimes and disorders before they happened. It can be told using a mosquito analogy; killing mosquitoes one by one is not the solution but drying the swamp is the solution. Community policing programs are considered effective in the U.S.

The last few decades have shifted police from a bureaucratic, incident driven force to a proactive service oriented organization. In this new era of policing, gaining public support and increasing citizens' satisfaction with police services has been a focal point.

A relatively large body of research has been conducted on CPA's impact on citizens' satisfaction with police. It is implied that almost everyone showed pro-police attitudes after CPA participation (Hilson, 1994, p.5). In addition, both citizens and police have learned reciprocal expectations, which would result in matching police and public priorities (Cohn, 1996). However, it should be noted that most of the CPA participants 
had already have positive perception of police prior to the academy (Hilson, 1994).

In order to enhance the community relations and to improve the citizens' satisfaction, police departments created community policing programs such as CPA's. It is noteworthy to state that CPA functions as an important tool to satisfy the tenets of new public service. Therefore, the policy makers should pay much attention on CPA and other innovative law enforcement programs in order to gain support from the citizens.

\section{References:}

Aryani, G. A., Garret, T.D. \& Alsabrook, C.L (May, 2000). The Citizen Police Academy. FBI Law Enforcement Bulletin, 69, 5, 10-16.

Bonello, E.M.\& Schafer,J.A. (2001). The citizen police academy: Measuring outcomes. Police Quarterly, 4(4), 434-448

Bumphus, V. W., Gaines, L. K., \& Blakely, C. R. (1999). Citizen police academies: Observing goals, objectives, and recent trends. American Journal of Criminal Justice, 24 (1), 67-79.

Cohn, G.E. (1996) The citizen police academy: A recipe for improving police-community relations. Journal of Criminal Justice 24(3), 265-271

Darcan, E. (2014) The impact of police-monitored CCTV cameras on crime patterns. LAP LAMBERT Academic Publishing. [Electronic version].

Denhardt, J. V. \& Denhardt, R.B. (2000). The New public Service: Serving rather than steering. Public Administration Review 60(6), 549-559. [Electronic version].

Denhardt, J. V. \& Denhardt, R.B. (2001). The New public Service: Putting democracy first. National Civic Review, 90(4), 391-400. [Electronic version]. Denhardt, J. V. \& Denhardt, R.B. (2003). The New Public Service: Serving, not steering. New York: M. E. Sharpe.

Enns, T. (1995). Citizens' police academies: The Fannington experience. Police Chief, 62, 133-35.

Greenberg, M. A. ( 1991 ). Citizen police academies. FBI Law Enforcement Bulletin, 60. 10- 13.

Greene, J.R. (1997, November). The case for community policing. Retrieved June 25, $2005 \quad$ from http://usinfo.state.gov/journals/itdhr/1197/ijde/greene/htm

Hawdon, J. \& Ryan, J. (2003). Police-resident interactions and satisfaction with police: An empirical test of community policing assertions. Criminal Justice Policy Review, 14,(1), 55-74

Hilson, J. (1994). Citizen police academies. Texas Law Enforcement Management and Administrative Statistics Program (TELEMASP) Bulletin, 1 May. 
Kapti, A. \& Alaç, A. (2013). Implementation process of public policy. (Eds.) M.Yıldız, Z. Sobacı. Public Policy: Theory and Implementation. Ankara: Adres Publication.

Kathi, P.C. \& Cooper T.L. (2005). Democratizing the administrative state: Connecting neighborhood councils and city agencies. Public Administration Review, 65(5), 559-567. [Electronic version].

Ling, R., Liqun, C., Lovrich, N. \& Gaffmey, M. (2005). Linking confidence in the police with the performance of the police: Community policing can make a difference. Journal of Criminal Justice, 33, 55-66. [Electronic version].

Lumb, R.C. \& Breazeale, R. (2003, March). Police officer attitudes and community policing implementation: Developing strategies for durable organizational change. Policing \& Society. 13(1), 91-107. [Electronic version].

Mintzberg, H. (1996). Managing government, governing management. Harvard Business Review, 74(3), 75-83.

Osborne, D. \& Gaebler, T. (1992). Reinventing Government: How the Entrepreneurial Spirit Is Transforming the Public Sector. Reading, MA: Addison-Wesley.

Palmiotto, M, J. \& Unninthan, N, P. (2002). The impact of citizen police academies on participants: An exploratory study. Journal of Criminal Justice, 30, 101-106

Peverly, W. J., and Phillips, E W. (1993). Community policing through citizen police academies. Police Chief, 60, pp.88-89.

Putnam, R.D. (1995). Bowling alone: America's declining social capital. Journal of Democracy, 6(1), 65-78. [Electronic version].

Roh, S., Oliver, W.M. (2005). Effects of community policing upon fear of crime: Understanding the casual linkage. Policing: An International Journal of Police Strategies \& Management, 28(4), 670-683. [Electronic version].

Stevens, D.J. (Ed.). (2002). Policing and community partnership. New Jersey: Upper Saddle River.

Stone, W.E. \& Champeny, S. (2001). Assessing a citizen police academy. Police Practice, 2(3), 219-241

Trojanowicz, R. \& Bucqueroux, B. (1990). Community policing: A contemporary perspective. Cincinnati,Oh: Andersen Publishing Company What's the Citizen Police Academy. Retrieved in December 1, 2004, from http://www.miamitwp.org/police/forms/cpa_application.pdf)

Whitman, S. (1993, June). Police academies for citizens. Law and Order, 41 (6), 66.

Xu, Y., Fiedler, M. L. \& Flaming, K. (2005). Discovering the impact of community policing: The broken windows thesis, collective efficacy, and 
citizens' judgment. Journal of Research in Crime and Delinquency, 42(2), 147-186. [Electronic version].

Zhao, J. S., He, N. \& Lovrich, N. P. (2003). Community policing: Did it change the basic functions of policing in the 1990s? A national follow-up study. Justice Quarterly, 20(4), 697- 723. [Electronic version].

Zhao, J. S., Scheider, M. C. \& Thurman, Q. (2002a). Funding community policing to reduce crime: have cops grants made a difference? Criminology \& Public Policy, 2(1), 7-32. [Electronic version].

Zhao, J., Scheider, M., \& Thurman, Q. (2002b). The effect of police presence on public fear reduction and satisfaction: A review of the literature.

The Justice Professional, 15, 273-299 